\title{
The Effect of Class-based Self-esteem Improvement Group Counseling Program on the Self-esteem in upper Grades of Elementary School
}

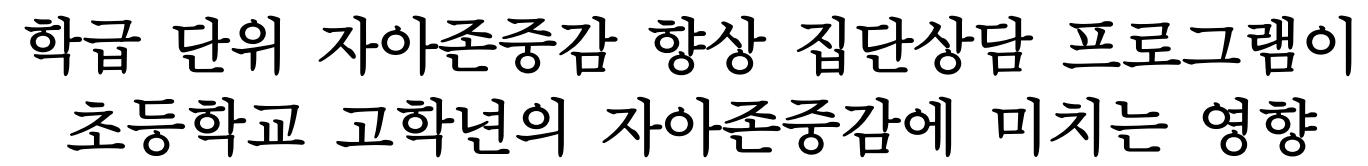

Jihyun $\mathrm{Kim}^{1}$, Hyundong Son ${ }^{2}$

김지현 ${ }^{1}$, 손현동2

${ }^{1}$ Teacher, Gwangju Eunbit ElementarySchool, Korea, shaman1052@naver.com

${ }^{2}$ Professor, Department of Education, Gwangju National University of Education, Korea, chamcoun@gnue.ac.kr

Corresponding author: Hyundong Son

\begin{abstract}
This study examines the effect of self-esteem improvement class-based group counseling program on the self-esteem in upper grades of elementary school. To this end, group counseling was conducted for a total of 10 sessions once or twice a week to the 6th grade pupils of an elementary school in G-metropolitan city. The collected data was analyzed using ANCOVA. As a result, not only the overall self-esteem score of the experimental group that implemented the self-esteem improvement program, but also the scores of the four sub-factors (general, social, familial, and academic) showed a significant difference from the control group. It proves that the self-esteem improvement class-based group counseling program that was adjusted for the COVID-19 outbreak has actually improved students' selfesteem. Next, suggestions on how to effectively conduct class-based group counseling in the context of COVID-19 are presented.
\end{abstract}

Keywords: Self-esteem, Higher Grades in Elementary School, Class-based Group Counseling, SelfEsteem Improvement Group Counseling Program

요약: 이 연구는 학급 단위의 자아존중감 향상 집단상담 프로그램을 COVID-19 상황에 맞춰 개발 한 후 아동의 자아존중감 향상에 미치는 효과를 알아보고자 시행되었다. 이를 위해 $\mathrm{G}$ 광역시 초등학교 6학년을 대상으로 실험집단에 주 1 2회씩(총 10회기) 자아존중감 향상 집단상담을 실시하였다. 수집된 자료는 공변량분석으로 통계처리하였다. 그 결과, 실험집단의 전체 자아존중감과 일반적, 사회적, 가정적, 학업적 네 가지 하위 요인 점수 모두가 통제집단과 유의한 차이를 보였다. 이 연구 결과는 COVID-19 상황에 맞게 운영된 자아존중감 프로그램이 학생들의 자아존중감을 향상시켰다는 데 의미가 있다. 이어 COVID-19 상황에서 학급 단위로 자아존중감 집단상담을 실시함에 있어 효율적인 운영 방법이 무엇인지를 제언하였다.

*This study is a revised and supplemented thesis for the first author's Master's degree (Gwangju National University of Education, 2021).

Received: March 15, 2021; 1st Review Result: April 29, 2021; 2nd Review Result: June 18, 2021

Accepted: July 31, 2021 
핵심어: 자아존중감, 초등학교 고학년, 학급 단위 집단상담, 자아존중감 향상 프로그램

\section{1. 서론}

왕따, 학교폭력, 자살시도, 불안, 우울 등의 정서적 어려움을 겪는 학생들의 호소가 초등학교 시절부터 시작된다는 것은 이제 충격적인 소식이 아니다. 비행청소년의 연령층이 점점 낮아지고 있고 양적으로도 증가 추세에 있으며 질적으로는 집단화, 조직화, 지능화되고 있어 커다란 사회문제로 떠오르고 있다[1]. 이러한 문제의 근본적인 원인이 무엇이고 또 근본적인 해결책은 무엇일지 깊이 고민해 볼 만하다. 여러 가지 원인이 있겠으나 여러 학자들은 이런 문제행동의 근원으로 낮은 자아존중감을 지적하였다. 즉 자아존중감은 자기 자신이 사랑받고 문제를 해결해나갈 수 있는 능력이 있는 존재라는 믿음인데, 이들이 속한 집단에서 지속적으로 거부되고 스스로 문제를 해결할 능력이 없다고 믿게 되면 자포자기하게 되고, 결국 비행행동을 하게 된다는 것이다.

초등학교 고학년 시기 아동들은 신체뿐 아니라 정신적으로도 많은 변화가 일어나는 시기이다. 이런 변화는 심리 및 정서적으로도 매우 불안정하게 만든다[2]. 게다가 학습량과 학습 수준이 높아져 많은 스트레스를 초래한다. 이런 불안정과 스트레스는 자아존중감을 낮춘다. 실제로 자아존중감은 초등학교에 입학한 후 1 2학년 시기에는 자신의 실제 능력과 상관없이 비현실적으로 높게 형성되어 있다가 초등학교 3 학년 시기부터 감소하기 시작하여 6학년이 되면 크게 낮아지는 것으로 밝혀졌다[3]. 이에 이 시기의 아동들이 바람직한 자아존중감을 갖도록 돕는 것이 중요하다[4]. 이 시기에는 자신을 탐색하고 수용하며, 동시에 타인으로부터의 긍정적 반응을 통해 자아존중감을 키워나가므로 아이들을 둘러싸고 있는 가정, 학교 등 생활환경 내에서 자아존중감을 향상시키기 위한 노력이 절실하다. 이러한 노력들 중 학교에서 할 수 있는 방법으로 집단 상담이 있다.

집단상담은 개개인이 가지고 있는 다양한 문제를 여러 사람과 집단을 이루어 상호작용하는 경험을 통해 해결하는 상담의 한 형태로 학교에서 교사가 한 번에 많은 학생들에게 교육적 서비스를 제공할 수 있는 주요 생활지도의 수단으로 볼 수 있다[5]. 특히 초등학생은 어른과 일대일로 진행되는 개인 상담보다 또래들과 함께하는 집단 상담을 더 편안하게 느끼며 이는 아동의 참여 수준을 높이는 데 도움이 된다. 아동은 또래와 도움을 주고받으며 긍정적 상호작용을 하고 자신의 행동과 생각에 대한 또래의 피드백을 얻기도 한다. 이 과정에서 아이는 소속감과 동료의식을 발달시키고 대인관계 기술을 연습하게 된다[6]. 학교 현장에서의 적용 용이성과 아동의 타인 수용 경험 극대화 및 대리학습의 기회 제공 등과 같은 집단상담의 장점을 최대로 이용하기 위해 자아존중감 향상 프로그램은 대부분 집단상담의 형식으로 진행되었고[7-14], 그 효과성이 입증되었다[15][16].

그러나 2020년 초반부터 국내에 급속히 퍼지기 시작한 COVID-19의 여파로 인해 사회적 거리 두기가 학교 수업 상황에서 권고되고 있기 때문에 집단 상담의 운영이 이전의 방식과는 다른 새로운 방법이 필요하다. 지금까지 학급 단위 집단 상담 프로그램 운영 방법을 살펴보면, 여러 연구[9][11][12][14]에서 반 전체를 대상으로 운영하되 소집단 모둠 활동으로 운영하였다. 이처럼 운영한 까닭은 학급 단위 집단 상담을 할 때 
소집단을 운영하지 않으면 개개인이 집단 상담에 참여할 수 있는 기회가 줄어들고 운영자 또한 개별 피드백을 주기 어렵기 때문이다. 4-5명의 소집단을 구성하여 활발한 상호작용을 하게 한 후 그 결과를 전체 학급과 상호작용하게 하여 공통점과 차이점을 찾으면서 집단 내 응집력을 높이는 방법을 쓰는 것이다[17].

이렇듯 소집단 활용은 집단상담 운영 시 필수적으로 사용되어온 효과적인 운영 방법이지만 COVID-19라는 시대적 변화에 적응하고 그에 맞는 집단상담 운영 방법을 고안할 필요가 있다. 이 연구에서의 연구 문제는 '학급 단위 자아존중감 향상 집단상담 프로그램은 초등학교 고학년의 자아존중감을 높이는 데 효과적인가?’이다.

\section{2. 연구방법}

\section{1 연구대상}

이 연구에서의 연구 대상은 $\mathrm{G}$ 광역시 $\mathrm{E}$ 초등학교 6학년 학생들로 실험집단은 제1 연구자가 담임을 맡고 있는 한 학급 학생 25 명(남 13 명, 여 12 명)이며, 통제집단은 학생들의 인지 능력과 가정환경이 비슷한 다른 학급 학생 25명(남 12명, 여 13명) 이었다.

\section{2 측정도구}

이 연구에서 사용한 도구는 Coopersmith[18]의 자존감 척도(Self Esteem Inventory, SEI)를 최보가와 전귀연[19]이 수정하여 재구성한 검사지이다. 이 검사지는 4 개 하위 요인(‘일반적', ‘사회적', ‘가정적', ‘학업적') 총 32문항이며 5점 Likert 척도 ('매우 그렇다'부터 '전혀 그렇지 않다')로 구성된 자기 평가 형식의 설문지이다. 이 연구에서의 신뢰도(Cronbach’s $\alpha$ )는 .927 이었다.

\section{3 연구 절차}

실험집단과 통제집단으로 선정된 6학년 두 학급을 대상으로 각 반의 담임교사가 동일한 시간과 안내에 따라 자아존중감 사전검사를 진행하였다. 그런 후 실험집단을 대상으로 매주 1 2회기씩 총 10회를 제1 연구자가 프로그램을 진행하였다. 프로그램을 진행한 기간은 COVID-19로 인해 등교가 어려워 중단되었던 기간을 포함해 총 12주(2020년 8월 21일부터 2020년 10월 26일까지) 이었다.

\section{4 자료 처리}

이 연구에서의 자료처리는 SPSS(Statistical Package for Social Science) 24.0을 이용하였다. 실험집단과 통제집단 평균 차이의 유의성을 검증하기 위하여 사전검사 점수를 공변량으로 한 공변량분석(ANCOVA)을 실시하였다. 그리고 양적 평가의 한계를 보완 하고자 소감문의 내용을 분석하였다.

\section{5 학급 단위 자아존중감 프로그램}

\subsection{1 프로그램 운영 방법}

학급 단위 집단상담은 한 집단의 수가 20 명이 넘어가는 경우가 많기 때문에 효과적인 
집단상담을 위해 운영방법을 고심할 필요가 있다. 왜냐하면 COVID-19 전염 예방을 위해 소집단 활용이 자유롭지 못하기 때문이다. 그래서 이런 경우 집단상담의 효과를 높이기 위해 필요한 것이 집단상담의 조직화와 구조화이다. 집단상담을 운영할 때 상담의 과정 을 구조화하는 것은 다양한 이점이 있다. 과정을 구조화하는 것은 프로그램의 도입-전개정리를 구조화하고 회기에 따라 전개 활동만 바꾸는 것이다. 이렇게 집단상담 진행을 구 조화하면 학생들은 그 과정에 금방 적응하고 심적 준비를 할 수 있으며 프로그램의 중점 활동을 할 수 있는 시간 확보에도 도움이 된다.

최신영[16]의 연구에 따르면 가장 효과적인 자아존중감 향상 프로그램 운영 방법은 시 행 횟수 8 10회, 주당 시행 횟수 2회, 회기 당 진행 시간 60 90인분 미만인 경우이다. 이 에 근거하여 집단상담 회기는 10 회기로 정하고 주당 횟수는 2 회를 기본으로 하되 COVID-19로 인해 등교수업이 중지된 주에는 1 회만 진행하였다. 회기 당 진행은 블록타 임으로 연 차시 80 분 수업으로 진행하였다.

집단상담의 기본 전개 과정은 도입, 활동, 마무리로 구성되었다. 도입 시 전체 릴레이 로 현재 기분을 발표하며 자신의 감정에 집중하기 시작한 후 중심 활동과 활동을 통한 목표를 소개한다. 중점 활동은 대략 60 분 소요되며 개별로 진행한다. 활동 후 시간이 허 락하는 한 전체 발표를 하며 시간이 부족한 경우 희망자만 발표한다. 희망자만 발표할 경우 다음 회기에서 이 전에 발표하지 않은 사람이 우선 발표하도록 한다. 마무리 활동 으로 이번 회기에서 느낀 점을 전체 릴레이로 발표하고 다음 시간에 대한 안내로 회기를 마친다.

\subsection{2 프로그램 내용}

이 연구에서 활용한 자아존중감 향상 집단상담 프로그램 회기 별 활동 내용은 선행연구[6-14]의 고찰 결과를 바탕으로 구성되었다.

1 회기에서는 총 10 회기 동안 창의적 체험활동 시간을 활용하여 진행할 것임을 학생들에게 구조화하여 안내한다. 집단상담 시간에 지켜야 할 규칙을 함께 정하고 비밀 엄수, 피드백을 줄 때 서로의 장점에 기초하여 배려하는 언어를 사용하기로 약속하는 등 중요한 내용에 대해 지킬 것을 서약한다. 이 프로그램에는 자기소개에 '명함 만들기' 활동이 소개되어 있으나 학생들이 직접 자신을 대표할 수 있는 별칭 또는 다른 사람이 나를 이렇게 불러주었으면 좋겠다는 별칭을 정하여 그 별칭으로 '아이엠 그라운드 게임'을 하며 친숙해지는 활동으로 재구성하였다.

자기수용 단계인 2 4회기까지의 내용은 다음과 같다. 우선 2회기는 자기수용 영역 중 자기 인식과 이해에 관련된 활동으로 자신의 장점을 찾아 홍보판을 만든 후 경매하는 활동이다. 개별 준비물을 자유롭게 이용하여 자신의 장점을 찾아 홍보판을 만들고 정해진 금액 내에서 자유롭게 서로의 장점을 사고파는 활동이다. 3 회기는 자기 수용 영역 중 자기 수용과 관련된 활동으로 인정 욕구에 대해 알아볼 수 있다. 동화 '너는 특별하단다'를 활용하여 다른 사람의 인정이 아닌 자기 격려를 통한 행동의 동기화가 이루어질 수 있도록 한다. 4회기는 자신의 심리적 변화를 이해하고 수용하는 활동이다. 심리적 변화에 따른 다양한 감정과 사고를 친구들과 함께 나누면서 나 혼자만 그런 것이 아니라는 보편성을 깨닫고 변화를 자연스럽게 받아들이면서 건설적으로 청소년기를 준비할 수 있도록 돕는 내용이다.

타인 수용 단계인 5 7회기까지의 내용은 다음과 같다. 우선 5회기는 타인 수용 중 
가족관계 이해 및 수용 영역으로 나와 가족관계를 인식하는 활동이다. 자신이 찰흙으로 만든 동물 가족을 만드는 활동이다. 6 회기는 가족과의 즐거웠던 경험을 탐색해 보는 회기이다. 가족과의 즐거웠던 경험을 앨범으로 만들면서 그때의 감정을 나누면서 가족의 소중함을 다시 느끼게 한다. 앨범을 그림으로 나타내기 어려울 경우에는 잡지나 사진을 이용해도 되고 스티커를 이용하는 등 다양한 방법으로 표현이 가능하다. 7회기는 친구의 관계를 인식하는 활동이다. 남녀, 나와 가까운 정도, 나에게 영향을 미친 정도에 따라 도식을 다르게 표현하면서 자기 주변 사람들과의 관계를 다시 생각해 보고 친구들 간에 서로 어떤 영향을 주고받는지 깨닫게 한다.

유능감과 성취감 단계인 8 9회기의 내용은 다음과 같다. 우선 8회기는 유능감 및 성취감 영역 중 협동 및 문제 해결 활동으로 친구와 함께 신문지를 가지고 놀이하며 협동심과 문제해결력을 키우는 회기이다. 신문지를 마음껏 찟어보면서 학교 안에서 많이 해본 적 없는 어지럽히기 등의 놀이를 한다. 이제 자기 주변에서 주울 수 있는 찢긴 신문지를 최대한 단단히 뭉쳐 각자의 공을 만들어 전체 학급을 두 팀으로 나누어 신문지 공으로 볼링 놀이를 한다. 9회기는 전지에 협동화를 그리는 활동으로 타인에 대한 신뢰감 및 단결력을 기를 수 있다. 이때 COVID-19 상황을 고려해 칠판에 전지를 두 장씩 붙여 놓고 사회적 거리 두기가 최대한 유지되고 공용 물품을 같이 쓰지 않기 위해서 1 , 2 모둠이 먼저 작업을 시작한다. 물감 등 물품은 시작 전 교사가 개별로 미리 나누어 준다. 모둠 별로 한 명씩 돌아가면서 나오고 자기 차례에서 핑거프린팅 또는 다른 도구를 사용하여 원하는 대로 꾸미고 자기 자리로 돌아간다. 차례대로 순서에 맞게 모둠원들이 돌아가면서 작품을 꾸미고 완성된 후 작품에 제목을 붙여 발표한다. 작품을 완성하면서 물감의 촉감을 느끼면서 즐거움을 느끼고 집단원들과 협력하여 하나의 작품을 완성하여 문제해결력을 기를 수 있다. 소집단원이 원하는 작품이 다를 경우 서로 작은 종이에 따로 작품을 만들어 이어 붙인다.

10 회기는 마무리 영역으로 자기평가 및 수용을 위한 활동이 진행된다. 자신의 긍정적 변화에 대해 인식하고 이를 격려하면서 변화된 나에게 점수를 주고 축하카드를 쓴다. 개별로 먹을 수 있는 간식을 마련하여 10 회기를 모두 마친 것을 축하하며 작은 파티를 연다. 자존감 선언문을 낭독하며 변화된 자신이 오랫동안 그 감정을 유지할 수 있도록 한다. 이때 자신의 변화를 작은 것에서 큰 것까지, 행동 및 사고의 변화 등 작은 것 하나라도 긍정적으로 변화한 것이 있는 찾아보도록 하고 이를 발표하며 서로 격려할 수 있도록 한다.

[표 1] 학급 단위 자아존중감 향상 프로그램

[Table 1] Class-based Self-esteem Improvement Program

\begin{tabular}{|c|c|c|c|c|c|c|}
\hline $\begin{array}{c}\text { 대 } \\
\text { 영 역 }\end{array}$ & $\begin{array}{l}\text { 하위 } \\
\text { 영역 }\end{array}$ & $\begin{array}{l}\text { 회 } \\
\text { 기 }\end{array}$ & 회기 명 & 목표 & 활동내용 & \\
\hline 관계형성 & $\begin{array}{l}\text { 자기 } \\
\text { 소개 }\end{array}$ & 1 & 나는요 & $\begin{array}{l}\text { ·집단상담의 목표 및 진행 } \\
\text { 방법 이해하기 } \\
\text { ·자기소개를 통한 집단 } \\
\text { 원과의 만남 }\end{array}$ & $\begin{array}{l}\text { ·프로그램 소개 } \\
\text { ·규칙 정하기 } \\
\text { ·나의 별칭 정하기 } \\
\text { ·별칭으로 아이엠 } \\
\text { 놀이하기 }\end{array}$ & 그라운드 \\
\hline
\end{tabular}


The Effect of Class-based Self-esteem Improvement Group Counseling Program on the Self-esteem in upper Grades of

\begin{tabular}{|c|c|c|c|c|c|}
\hline \multirow{3}{*}{ 자기수용 } & $\begin{array}{l}\text { 자기 } \\
\text { 인식과 } \\
\text { 이해 }\end{array}$ & 2 & $\begin{array}{l}\text { 나는 } \\
\text { 특별해요 }\end{array}$ & $\begin{array}{l}\text {.나의 장점 및 강점 찾 } \\
\text { 기 }\end{array}$ & $\begin{array}{l}\text {.나의 장점을 찾아 홍보판 만 } \\
\text { 들기 } \\
\text {.나의 장점 경매하기 }\end{array}$ \\
\hline & \multirow[t]{2}{*}{$\begin{array}{l}\text { 자기 } \\
\text { 수용 }\end{array}$} & 3 & $\begin{array}{c}\text { 나는 } \\
\text { 중요해요 }\end{array}$ & $\begin{array}{l}\text {-인정 욕구의 의미 이해 } \\
\text { 하기 } \\
\text {-자기를 격려하는 사고 } \\
\text { 하기 }\end{array}$ & $\begin{array}{l}\text { ·동화를 통해 인정욕구 의미 } \\
\text { 알아보기 } \\
\text { ·노력했음에도 인정을 받지 못한 } \\
\text { 경험 떠올리기 } \\
\text {.다른 사람의 인정 대신 자기 } \\
\text { 격려하기 }\end{array}$ \\
\hline & & 4 & $\begin{array}{l}\text { 나는 } \\
\text { 변하고 } \\
\text { 있어요 }\end{array}$ & $\begin{array}{l}\text {.나의 심리적 변화 이해 } \\
\text { 하고 수용하기 }\end{array}$ & $\begin{array}{l}\text {.나의 심리적 변화에 대해 알 } \\
\text { 아보기 } \\
\text { ·우리들 마음의 공통점 찾고 } \\
\text { 공유하기 }\end{array}$ \\
\hline \multirow{3}{*}{ 타인수용 } & \multirow{2}{*}{$\begin{array}{l}\text { 가족 } \\
\text { 관계 } \\
\text { 이해 } \\
\text { 및 } \\
\text { 수용 }\end{array}$} & 5 & $\begin{array}{c}\text { 우리 } \\
\text { 가족은요 }\end{array}$ & $\begin{array}{l}\text { ·가족에 대한 나의 인식 } \\
\text { 알아보기 }\end{array}$ & $\begin{array}{l}\text { 찰흙으로 가족을 동물로 표 } \\
\text { 현하고 소개하기 }\end{array}$ \\
\hline & & 6 & $\begin{array}{l}\text { 가족과 } \\
\text { 함께하면 } \\
\text { 즐거워요 }\end{array}$ & $\begin{array}{l}\text { ·가족과 행복했던 추억 } \\
\text { 을 떠올리기 }\end{array}$ & $\begin{array}{l}\text { ·가족과의 좋은 추억을 앨범 } \\
\text { 으로 만들기 } \\
\text { ·그때의 나의 감정 나누기 }\end{array}$ \\
\hline & $\begin{array}{l}\text { 또래 } \\
\text { 관계 } \\
\text { 이해 } \\
\text { 및 수용 }\end{array}$ & 7 & 친구와 나는요 & $\begin{array}{l}\text {.나와 주변 친구관계를 } \\
\text { 인식하기 }\end{array}$ & $\begin{array}{l}\text {.나와 친구의 관계도 그리고 } \\
\text { 발표하기 }\end{array}$ \\
\hline \multirow{2}{*}{$\begin{array}{l}\text { 유능감 } \\
\text { 및 } \\
\text { 성취감 }\end{array}$} & \multirow{2}{*}{$\begin{array}{l}\text { 협동 } \\
\text { 및 } \\
\text { 문제 } \\
\text { 해결 }\end{array}$} & 8 & $\begin{array}{l}\text { 친구와 같이 } \\
\text { 놀아요 }\end{array}$ & $\begin{array}{l}\text { 친구와 함께 놀이하며 협동심 } \\
\text { 을 기르고 친구의 소중함 깨닫 } \\
\text { 기 }\end{array}$ & $\begin{array}{l}\text { ·마음껏 신문지 찢기 } \\
\text { ·찟은 신문지로 공 만들기 } \\
\text { ·신문지 공으로 볼링하기 }\end{array}$ \\
\hline & & 9 & 함께 그려요 & $\begin{array}{l}\text { ·친구들과 협동하여 단 } \\
\text { 결력을 기르고 문제해결 } \\
\text { 력 키우기 }\end{array}$ & $\begin{array}{l}\text { ·전지나 우드락에 핑거프린팅 } \\
\text { 물감을 이용하여 협동화 만들 } \\
\text { 기 } \\
\text { ·함께한 경험 나누기 }\end{array}$ \\
\hline 마무리 & $\begin{array}{l}\text { 자기 } \\
\text { 평가 } \\
\text { 및 } \\
\text { 수용 }\end{array}$ & 10 & $\begin{array}{c}\text { 나는 } \\
\text { 자랑스러워요 }\end{array}$ & $\begin{array}{l}\text {-자신의 변화된 점을 찾 } \\
\text { 고 축하하기 }\end{array}$ & $\begin{array}{l}\text { ·변화된 나를 칭찬해주고 상 } \\
\text { 장주기 } \\
\text { ·축하 파티 하기 } \\
\text { ·자존감 선언문 낭독하기 }\end{array}$ \\
\hline
\end{tabular}

\section{3. 연구결과}

\section{1 학급 단위 자아존중감 향상 프로그램이 자아존중감에 미치는 효과}

실험집단과 통제집단의 사전과 사후 자아존중감 검사 결과를 살펴보면 자아존중감 전 체 점수뿐 아니라 모든 하위 영역에서 실험집단의 평균은 상승했음을 알 수 있다 ([표 2] 참조). 
[표 2] 자아존중감 사전-사후 검사 평균과 표준편차

[Table 2] Self-esteem Pre-Post Test Mean and Standard Deviation

\begin{tabular}{|c|c|c|c|c|c|c|c|c|}
\hline \multirow{2}{*}{ 영역 } & \multirow{2}{*}{ 집단 } & \multirow{2}{*}{$N$} & \multicolumn{2}{|c|}{ 사전 } & \multicolumn{2}{|c|}{ 사후 } & \multicolumn{2}{|c|}{ 조정 } \\
\hline & & & $M$ & $S D$ & $M$ & $S D$ & $M$ & $S E$ \\
\hline \multirow{2}{*}{ 일반적 } & 실험 & 25 & 3.63 & 0.73 & 4.15 & 0.53 & 4.16 & 0.64 \\
\hline & 통제 & 25 & 3.71 & 0.90 & 3.79 & 0.82 & 7.77 & 0.64 \\
\hline \multirow{2}{*}{ 사회적 } & 실험 & 25 & 2.91 & 0.74 & 3.51 & 0.87 & 3.52 & 0.93 \\
\hline & 통제 & 25 & 2.94 & 0.91 & 3.13 & 0.90 & 3.11 & 0.93 \\
\hline \multirow{2}{*}{ 가정적 } & 실험 & 25 & 3.58 & 0.98 & 3.95 & 0.83 & 4.10 & 0.83 \\
\hline & 통제 & 25 & 4.00 & 0.75 & 3.95 & 0.87 & 3.39 & 0.83 \\
\hline \multirow{2}{*}{ 학업적 } & 실험 & 25 & 3.79 & 0.69 & 4.02 & 0.57 & 3.97 & 0.84 \\
\hline & 통제 & 25 & 3.64 & 0.71 & 3.33 & 0.69 & 3.36 & 0.84 \\
\hline \multirow{2}{*}{ 전체 } & 실험 & 25 & 3.45 & 0.64 & 3.88 & 0.52 & 3.91 & 0.51 \\
\hline & 통제 & 25 & 3.56 & 0.61 & 3.54 & 0.66 & 3.49 & 0.51 \\
\hline
\end{tabular}

공변량분석(ANCOVA)을 실시한 결과, 자아존중감 전체 점수는 실험집단과 통제집단에 통계적으로 유의 미한 차이가 있는 것으로 나타났다([표 3] 참조). 하위 영역별로도 일반적, 사회적, 가정적, 학업적 하위 요 인 모두에서 실험집단과 통제집단 간에 유의한 차이를 보였다.

[표 3] 자아존중감 검사의 공변량분석 결과

[Table 3] ANCOVA Results of Self-esteem Test

\begin{tabular}{|c|c|c|c|c|c|c|}
\hline 영역 & 변량원 & $S S$ & $d f$ & $M S$ & $F$ & $p$ \\
\hline \multirow{3}{*}{ 일반적 } & 사전검사 & 9.677 & 1 & 9.677 & 33.910 & .000 \\
\hline & 집단 & 1.932 & 1 & 1.932 & 6.769 & .012 \\
\hline & 오차 & 13.412 & 47 & 0.285 & & \\
\hline \multirow{3}{*}{ 사회적 } & 사전검사 & 25.037 & 1 & 25.037 & 93.613 & .000 \\
\hline & 집단 & 2.004 & 1 & 2.004 & 7.491 & .009 \\
\hline & 오차 & 12.570 & 47 & 0.267 & & \\
\hline \multirow{3}{*}{ 가정적 } & 사전검사 & 23.437 & 1 & 23.437 & 97.838 & .000 \\
\hline & 집단 & 1.312 & 1 & 1.312 & 5.477 & .024 \\
\hline & 오차 & 11.259 & 47 & 0.240 & & \\
\hline \multirow{3}{*}{ 학업적 } & 사전검사 & 6.044 & 1 & 6.044 & 21.595 & .000 \\
\hline & 집단 & 4.658 & 1 & 4.658 & 16.643 & .000 \\
\hline & 오차 & 13.154 & 47 & 0.280 & & \\
\hline \multirow{3}{*}{ 전체 } & 사전검사 & 9.722 & 1 & 9.722 & 63.136 & .000 \\
\hline & 집단 & 2.165 & 1 & 2.165 & 14.057 & .000 \\
\hline & 오차 & 7.237 & 47 & 0.154 & & \\
\hline
\end{tabular}




\section{2 소감문 분석 결과}

참여 학생들로부터 목표 별 회기 프로그램 구성에 대한 구체적인 피드백을 얻고자 진 행했던 프로그램 중 특별히 인상적이었던 프로그램, 도움이 되었던 프로그램에 표시하고 간단히 그 이유를 써주도록 하였다. 회기별로 특별히 도움이 되었다고 응답한 학생들의 숫자와 그 이유에 대한 진술 발췌 요약한 결과 친구와 함께 어울리는 활동으로 구성된 유능감 및 성취감 영역이 가장 도움이 되었던 회기로 나타났다([표 4] 참조). 또한, 타인 수용 영역 중 가족을 찰흙으로 만들어 소개하는 활동과 가족 앨범 만들기 활동이 16 명이 응답하여 가장 적은 빈도를 보였는데 이는 초등학교 6학년 학생들의 관심 영역이 가족에 서 또래 관계로 옮겨가고 있음을 보여준다.

[표 4] 회기 목표별로 도움이 되었다고 진술한 내용

[Table 3] Statements that were Helpful for Each Session Goal

\begin{tabular}{|c|c|c|c|}
\hline $\begin{array}{l}\text { 관련 } \\
\text { 목표 }\end{array}$ & 주요 활동 & $\begin{array}{l}\text { 빈도 } \\
(N)\end{array}$ & 진술 내용 \\
\hline $\begin{array}{l}\text { 관계 } \\
\text { 형성 }\end{array}$ & $\begin{array}{l}\text { '나는요' } \\
\text {-별칭 정하기 } \\
\text {-별칭으로 아이엠그라운드 놀이하기 }\end{array}$ & 17 & $\begin{array}{l}\text { ·친구들에 대해 더 잘 알 수 있었음(6) } \\
\text { ·나의 특징을 생각해볼 수 있었음(7) }\end{array}$ \\
\hline \multirow{3}{*}{$\begin{array}{l}\text { 자기 } \\
\text { 수용 }\end{array}$} & $\begin{array}{l}\text { ‘나는 특별해요' } \\
\text {-나의 강점과 장점을 찾아 홍보판 만들고 장점 } \\
\text { 경매 하기 }\end{array}$ & 20 & .나의 장점을 새롭게 알게 된 점(15) \\
\hline & $\begin{array}{l}\text { ‘나는 중요해요' } \\
\text {-동화를 통해 인정욕구 의미 알아보기 } \\
\text {-다른 사람의 인정대신 자기 격려하기 }\end{array}$ & 17 & $\begin{array}{l}\text { 인정을 받고 싶었던 내 마음이 이해되고 내가 나를 } \\
\text { 인정해주게 된 점(14) }\end{array}$ \\
\hline & $\begin{array}{l}\text { ‘나는 변하고 있어요' } \\
\text {-나의 심리적 변화에 대해 알아보고 마음의 공 } \\
\text { 통점 공유하기 }\end{array}$ & 18 & $\begin{array}{l}\text { ·마음이 후련해 짐(3) } \\
\text { ·나만 그런 것이 아니라는 생각(12) }\end{array}$ \\
\hline \multirow{3}{*}{$\begin{array}{l}\text { 타인 } \\
\text { 수용 }\end{array}$} & $\begin{array}{l}\text { ‘우리 가족은요' } \\
\text {-찰흙으로 동물 가족 만들기 } \\
\text {-가족 구성원에 대해 소개하기 }\end{array}$ & 16 & $\begin{array}{l}\text { ·가족에 대해 다시 생각해 봄(12) } \\
\text { ·가족을 소개해서 좋았음 }\end{array}$ \\
\hline & $\begin{array}{l}\text { ‘가족과 함께하면 즐거워요' } \\
\text {-가족과의 즐거웠던 경험을 앨범으로 만들기 }\end{array}$ & 16 & $\begin{array}{l}\text { ·가족과 즐거웠던 기억이 많았음(10) } \\
\text { ·가족의 소중함을 느낌(3) }\end{array}$ \\
\hline & $\begin{array}{l}\text { ‘친구와 나는요' } \\
\text {-나와 친구의 관계도 그리기 }\end{array}$ & 18 & $\begin{array}{l}\text { ·친구가 많다는 걸 깨달음(7) } \\
\text { ·잊고 있던 친구가 그리워짐(4) } \\
\text { ·친구의 소중함을 느낌(3) }\end{array}$ \\
\hline \multirow{2}{*}{$\begin{array}{l}\text { 유능 } \\
\text { 감 } \\
\text { 및 } \\
\text { 성취 } \\
\text { 감 }\end{array}$} & $\begin{array}{l}\text { ‘친구와 같이 놀아요' } \\
\text {-신문지 찢기 놀이 } \\
\text {-신문지로 공 만들어 볼링하기 }\end{array}$ & 22 & $\begin{array}{l}\text {.아무 생각 없이 친구들과 놀아서 좋았음(스트레스 } \\
\text { 해소)(20) }\end{array}$ \\
\hline & $\begin{array}{l}\text { ‘함께 그려요' } \\
\text {-전지에 핑거프린팅 물감을 이용하여 협동화 만 } \\
\text { 들기 }\end{array}$ & 20 & $\begin{array}{l}\text { ·친구들과 어릴 때로 돌아가서 노는 것 같아 재미있 } \\
\text { 었음(12) } \\
\text { ·협동하는게 좋았음(5) }\end{array}$ \\
\hline $\begin{array}{l}\text { 마무 } \\
\text { 리 }\end{array}$ & $\begin{array}{l}\text { '나는 자랑스러워요' } \\
\text {-나에게 축하카드 쓰기 } \\
\text {-자존감 선언문 낭독하기 }\end{array}$ & 20 & $\begin{array}{l}\text { ·내가 변함을 느껴서 뿌듯함(나의 변화를 다시 생각 } \\
\text { 하게 됨)(13) } \\
\text { ·내가 소중함을 느낌(2) } \\
\text { ·의미 있었음(2) }\end{array}$ \\
\hline
\end{tabular}




\section{4. 논의}

이 연구는 초등학교 고학년 특성에 맞추어 기존의 자아존중감 향상 집단상담 프로그램 을 구성하여 적용한 후 그 효과성을 검증하고 COVID-19 상황에서 학급 집단 상담 운영 의 방법적 측면을 연구하는데 목적이 있다. 연구를 통해 도출된 주요 결과를 선행연구에 비춰 논의하면 다음과 같다.

먼저, 이 연구에서 COVID-19 상황에 맞게 구안하여 실시한 자아존중감 향상 집단상담 프로그램은 양적·질적 분석 결과 효과가 있음이 입증되었다. 이는 3학년 대상[12], 4학년 대상[14], 5학년 대상[7][8]으로 자아존중감 향상 프로그램을 적용한 연구결과와도 일치한 다. 다만 이들 연구들과는 자아존중감 향상 프로그램을 사용한 공통점이 있으나 집단상 담 운영 방법 면에서 두 개의 선행 연구[12][14]에서는 반을 소집단으로 나누어 운영하였 지만 이 연구에서는 반 전체를 한 집단으로 운영한 차이점이 있었다. 그리고 COVID-19 상황으로 인해 학생들이 등교하는 날에만 주 1회 또는 2회 띄엄띄엄 진행되어 연속적으 로 진행되었던 다른 연구들과도 차이가 있었다. 이런 운영방식의 차이가 프로그램의 효 과에 영향을 주었는지를 알아보기 위해 효과 크기 $(d)[20]$ 를 구해 비교해보면, 이 연구는 중간 효과 크기 정도인 0.57 이었다. 아동을 대상으로 한 자아존중감 프로그램에 대한 메 타분석 연구들[15][16]에서 밝혔던 효과 크기였던 0.89와 1.03에 비하면 작으나 이루미[12] 의 연구는 0.52 , 이선미[14]의 연구는 0.74 였던 것에 비하면 모두 중간 효과 크기로 차이 를 보이지 않았다. 이 결과는 현재의 상황처럼 활발한 소집단 상호작용이 어려울 때는 반 전체를 대상으로 한 방식도 효율적으로 운영이 된다면 소집단으로 운영한 것과 큰 효 과 차이를 보이지 않을 수 있다는 것을 시사한다.

또한 자아존중감 하위 영역인 일반적, 사회적, 가정적, 학업적 자아존중감의 사후 검사 결과를 실험집단과 통제집단 간에 비교해 본 결과 자아존중감의 모든 하위 요인에서 유 의한 차이를 보였다. 이는 여러 연구들에서 하위 요인들 중 한 가지 이상의 하위 영역에 서 유의한 차이를 보이지 않았다는 연구들과는 대조적이다. 그중 가정적 자아존중감 영 역에서 유의미한 결과가 도출되지 않았던 선행 연구들[7][8][10][12][14]과 이 연구의 차이 점은 프로그램의 내용 및 집단 운영 방식에서 효과 차이를 찾기보다 다른 환경적 측면에 서 생각해 볼 수 있다. 가정적 자아존중감은 어린 시절부터 축적된 가족들과의 긍정적인 상호작용에 큰 영향을 받는 부분으로 학교에서만 진행하는 자아존중감 집단 상담을 통해 가정 내 가족들의 상호작용이 바로 바뀌지는 않으므로 학생의 가정적 자아존중감이 즉각 적으로 향상을 보이기 어렵다. 하지만 제 1 연구자가 근무하는 학군은 경제적으로 안정되 어 있고 부모님과 주말에 시간을 많이 보내는 학생들이 많은 학교임을 감안하여 볼 때, 학생들이 평소에 당연하게 여기던 것들이 당연하지 않음을 깨닫기에 충분했다고 보인다. 학생들의 소감문 반응을 보면 학생들이 가족의 가치에 대해 새로운 각도로 접근하는 계 기가 되었으며 내가 생각한 것보다 내가 가족과 추억이 많고 사랑을 받고 있음을 느끼게 되었다고 보고한 학생들이 많은 것이 이를 뒷받침한다. 학교에서 이루어지는 집단 상담 이 가정 내 상호작용의 모습을 바꿀 수는 없으나 개인이 가정 내 상호작용을 어떻게 바 라오는지에 관점을 변화시킬 수 있다고 볼 수 있다.

그러나 이 프로그램이 COVID-19 상황에서 학급 전체를 대상으로 더욱 효과적으로 운 영되기 위한 제언을 하면 다음과 같다. 우선 1 회기를 80 분 블록타임으로 운영하며 최소 10 회기 이상은 진행해야 한다. 왜냐하면 이 프로그램의 도입 활동이었던 '현재 나의 기분 나누기'는 본 활동 이전에 학생들이 진지하게 프로그램에 참여할 마음의 준비를 하고 자 
신의 감정에 집중하게 하는 데 도움을 주었고 학생 모두가 발표하도록 하기 위해서는 시 간을 충분히 확보하는 것이 중요하기 때문이다. 마찬가지로 마무리 활동으로 '이번 활동 을 통해 느낀 점 공유하기'도 모든 학생이 돌아가며 발표하는 것이 상호 간 공통점을 느 끼고 집단이 응집성을 갖도록 하는 데 도움을 주었다. 이와 더불어 충분한 본 활동 시간 확보를 위해 블록타임 운영은 매우 필요하다 할 수 있다. 그리고 프로그램 종결 후 반응 및 만족도 설문조사에서 참여자들의 대다수가 가장 도움이 되었던 활동으로 신문지로 놀 이하기, 핑거페인팅 물감으로 그림 그리기 활동을 꼽으며 활동 후 교우관계에 더 자신감 이 생겼다고 보고하였고 친구들과 노는 시간이 더 많았으면 좋겠다고 설문지에 응답한 결과도 있었다. 이에 추후 프로그램을 구성할 때 친구들과 함께 해결하는 협동 과제들을 추가하는 것이 학생들의 실생활에 더 도움이 되는 방향일 것으로 보인다.

또한, 이러한 COVID-19 상황으로 학급 전체를 한 집단으로 원활하게 집단상담을 운영 하기 위해서는 회기의 과정을 구조화해 학생들이 그 과정에 익숙하게 하는 것이 도움이 된다. 기본적인 회기 전개는 현재 나의 느낌이나 기분 말하기(전체), 차시 목표 소개, 개 인별 본 활동, 활동 결과 발표(전체 또는 시간이 부족할 경우 희망자), 활동 소감 나누기 (전체), 마치기 단계이다. 초등학교 고학년 학생들은 빠르고 안정적이게 이 단계에 적응하 여 집단 상담이 시작되었을 때 분위기 조성이 더 잘 되었고 중심 활동 시간 확보 및 빠 른 뒷정리 등 원활한 프로그램 진행에 도움이 되었다. 초등학교 고학년뿐 아니라 전 학 년에서 구조화된 집단 상담 진행은 학생들에게 안정감을 주어 원활한 진행에 도움이 될 것이다. COVID-19상황으로 소집단 활동이 제한되어 학급 전체를 한 집단으로 운영했던 방법이 학생들에게 학급 구성원 전체에게 관심을 갖게 되는 계기가 되었고 실험 처치 결 과도 선행연구와 마찬가지로 긍정적이었기 때문에 앞으로도 이 프로그램을 운영하고자 하는 운영자는 소집단을 나누지 않고 전체로 운영하는 것도 효과적인 방법이 될 것이다.

\section{References}

[1] I. W. Kang, Analysis and new trends of brutalized teenager's crime and the solutions, Asia-pacific Journal of Multimedia Services Convergent with Art, Humanities and Sociology, (2019), Vol.9, No.10, pp.739-751, DOI: http://dx.doi.org/10.35873/ajmahs.2019.9.10.063

[2] O. B. Jeong, Social and emotional development, Seoul, Hakjisa, (2017)

[3] H. H. Kim, K. Y. Kim, Children's self-esteem: Dimensions and development, Korean Journal of Child Studies, (1993), Vol.14, No.1, pp.129-139.

[4] H. K. Cho, H. D. Son, The effect of bibliotherapy utilizing Korean language textbook of 2009 educational curriculum revision on the self-esteem of elementary school students, Korean Journal of Educational Therapist, (2015), Vol.7, No.3, pp.375-392, UCI: G704-SER000003939.2015.7.3.004

[5] J. R. Kang, Group counseling in practice (3rd ed.), Seoul, Hakjisa, (2019)

[6] E. S. Kim, H. D. Son, The principles and practices of self-esteem improvement, Seoul, Hakjisa, (2016)

[7] W. S. Cho, The effects of the self-esteem enhancement program on children's self-esteem and motivation of learning, The Graduate School of the Korea University of Education, Master's thesis, (1996)

[8] H. M. Song, (The) Effects of the self-esteem enhancement program on elementary school students, Hannam University Graduate School of Education, Master's thesis, (2004)

[9] S. H. Park, The effects of the self-esteem enhancement program applied to the unit of a class on the self-esteem of elementary school students, Kyungpook National University Graduate School of Education, Master's thesis, (2010) 
[10] J. S. Lim, The effect of self-esteem promotion group counseling on the improvement of self-esteem of elementary school students, Hankuk University of Foreign Studies Graduate School, Master's thesis, (2011)

[11] H. S. Min, Study on the effect of positive self-esteem improvement program on self-worth of elementary students, Woosuk University, Graduate School of Education, Master's thesis, (2015)

[12] R. M. Lee, The effects of the self-esteem enhancement group counseling applied to the unit of a class on the selfesteem and school adjustment of elementary school students, Gwangju National University of Education Graduate School, Master's thesis, (2016)

[13] D. H. Kim, The effect of encouragement group counseling program on the self-efficacy of elementary school students, Busan National University of Education Graduate School, Master's thesis, (2018)

[14] S. M. Lee, H. D. Son, E. S. Kim, The effect of a class-based self-esteem improvement program on elementary school students' self-esteem and ego-resilience, The Journal of Learner-Centered Curriculum and Instruction, (2019), Vol.19, No.2, pp.815-838, DOI: 10.22251/jlcci.2019.19.2.815

[15] S. J. Lee, I. J. Chung, A meta-analysis of self-esteem enhancement programs for children, Health and Social Welfare Review, (2018), Vol.38, No.3, pp.45-74, DOI: https://doi.org/10.15709/hswr.2018.38.3.45

[16] S. Y. Choi, I. H. Ahn, Meta Analysis about Group Counseling for Improvement of Self-Esteem for Elementary School Students, The Korean Journal of Elementary Counseling, (2012), Vol.12, No.1, pp.13-32, UCI: G704SER000003102.2013.12.1.004

[17] J. G. Lee, Group Counseling Practice and Research at School, Seoul, Kyoyookbook, (2013)

[18] S. Coopersmith, The Antecedents of self-esteem, (1st edition ), W. H. Freeman and Co, (1967)

[19] B. G. Choi, G. Y. Jeon, A Study on the Development of"the Self-Esteem Inventory"(I), Journal of the Korean Home Economics Association (1993), Vol.31, No.2, pp.41-54.

[20] J. Cohen, Statistical power analysis for the behavioral sciences, (1st Edition.), Academic Press, (1977) 